\title{
Multi-Analytical Approach for Characterization of Archaeological Meroatic Potsherds
}

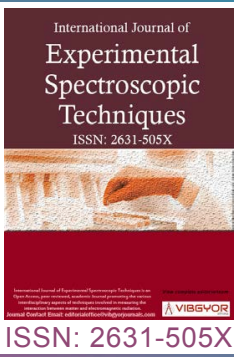

\section{Fatima Elbashir Siddig', Abdalla Ahmed Elbashir ${ }^{*}$ and Verena Lepper ${ }^{2}$}

\author{
${ }^{1}$ Department of Chemistry, Faculty of Science, University of Khartoum, Khartoum, Sudan \\ ${ }^{2}$ Ägyptisches Museum und Papyrussammlung, Staatliche Museen zu Berlin - Preußischer Kulturbesitz, Germany
}

\begin{abstract}
In this paper, the results obtained using a multi-analytical approach for characterization of six potsherds originally attributed to the $4^{\text {th }}$ century BC excavated from Meroatic sites, Sudan were reported. Sort of the minerals and their structural deformation during the production forming process from the raw material used by artisan to ware were performed, in the particular, the maximum heating temperature obtained during burial and operative condition (open or close condition) of the kiln were performed by Fourier Transform Infrared Spectroscopy (FT$I R)$, X-Ray Diffraction (XRD) and thermogravimetric analysis (TGA) was the completing analysis to estimate the firing temperature from typical thermal reactions in potsherds. Further X-ray Ray Fluorescence, Scanning Electron Microscope (SEM) coupled with Energy Dispersive $\mathrm{X}$-ray spectrometer (EDX) were used to analyze the morphology, chemical composition and find subsequent progress of vitrification levels. The XRD results give supportive information obtained from the FT-IR spectra. X-ray diffractometry results have shown the existence of quartz, albite (MER-02, MER-04, MER-06) anatase (MER-03) and manganite (MER-05) minerals. Thus, the mineralogical structure of a potsherds samples has a quite dissimilar composition that could suggest that different source of the raw material utilized for the potsherds production. Clay minerals can be used for re-establishment of previous production conditions. In the present paper TGA, FT-IR and XRD results potsherds are examined and information derived on potsherds technologies regarding raw materials and production conditions is confirmed by SEM observations relating to the extent of vitrification. The temperature at which potsherds were fired differs over range $\left(700-900^{\circ} \mathrm{C}\right)$ depending on the sort of clay used and the kiln existing. The obtained data point out that the investigated potsherds were made from different raw materials and workshops.
\end{abstract}

\section{Keywords}

FT-IR, XRD, XRF, SEM-EDX, TGA, Potsherds

\section{Introduction}

Meroe is located on the east bank of the Nile about 200 km north-east of Khartoum. The site con- tains the residues of the Royal City and close pyramid fields of the antique Kingdom of Kush [1,2]. Meroitic pottery is possibly the most broadly well-

* Corresponding author: Abdalla Ahmed Elbashir, Department of Chemistry, Faculty of Science, University of Khartoum, Khartoum, Sudan, Tel: +249912989405

Accepted: March 23, 2019; Published: March 25, 2019

Copyright: (C 2019 Siddig FE, et al. This is an open-access article distributed under the terms of the Creative Commons Attribution License, which permits unrestricted use, distribution, and reproduction in any medium, provided the original author and source are credited.

Siddig et al. Int J Exp Spectroscopic Tech 2019, 4:023

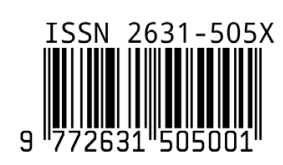


Table 1: Description of pottery samples.

\begin{tabular}{|c|c|c|c|c|c|c|c|c|c|}
\hline \multirow{2}{*}{$\begin{array}{l}\text { Sample } \\
\text { code }\end{array}$} & \multirow[t]{2}{*}{ SNM $^{*}$} & \multirow[t]{2}{*}{ Location } & \multicolumn{7}{|l|}{ Typology } \\
\hline & & & Fabric & Colour & Polishing & $\begin{array}{l}\text { Raw } \\
\text { materials }\end{array}$ & $\begin{array}{l}\text { Type of } \\
\text { factory }\end{array}$ & Decoration & $\begin{array}{l}\text { Pottery } \\
\text { part }\end{array}$ \\
\hline MER-01 & $9984^{*}$ & Abu Geili & $\begin{array}{l}\text { Meroitic } \\
\text { very fine, } \\
\text { smooth } \\
\text { dense paste }\end{array}$ & $\begin{array}{l}\text { Colour: } \\
\text { Light } \\
\text { white }\end{array}$ & $\begin{array}{l}\text { Very soft } \\
\text { and fine }\end{array}$ & Kaolinite & $\begin{array}{l}\text { Made } \\
\text { by } \\
\text { wheel }\end{array}$ & $\begin{array}{l}\text { Painting with } \\
\text { brown lines } \\
\text { and light } \\
\text { brown circle }\end{array}$ & Body \\
\hline MER-02 & $2941^{*}$ & Royal city & $\begin{array}{l}\text { Meroitic } \\
\text { dark utility }\end{array}$ & Black & $\begin{array}{l}\text { Soft and } \\
\text { fine }\end{array}$ & $\begin{array}{l}\text { Nile valley } \\
\text { clay }\end{array}$ & $\begin{array}{l}\text { Made } \\
\text { by } \\
\text { wheel }\end{array}$ & $\begin{array}{l}\text { Straight lines } \\
\text { with tringles } \\
\text { which filled by } \\
\text { dotted lines }\end{array}$ & Rim \\
\hline MER-03 & $2928^{*}$ & Kawa & $\begin{array}{l}\text { Meroitic } \\
\text { very fine, } \\
\text { smooth } \\
\text { dense paste }\end{array}$ & $\begin{array}{l}\text { Colour: } \\
\text { Light } \\
\text { tan } \\
\text { brown/ } \\
\text { red }\end{array}$ & Very soft & Kaolinite & $\begin{array}{l}\text { Made } \\
\text { by } \\
\text { wheel }\end{array}$ & $\begin{array}{l}\text { Painted man } \\
\text { sherd }\end{array}$ & Body \\
\hline MER-04 & $2868^{*}$ & Royal city & $\begin{array}{l}\text { Meroitic } \\
\text { red-brown } \\
\text { utility }\end{array}$ & Red & Soft & $\begin{array}{l}\text { Nile valley } \\
\text { clay }\end{array}$ & $\begin{array}{l}\text { Made } \\
\text { by } \\
\text { wheel }\end{array}$ & Undecorated & $\operatorname{Rim}$ \\
\hline MER-05 & $2924^{*}$ & Royal city & $\begin{array}{l}\text { Meroitic } \\
\text { very fine, } \\
\text { smooth } \\
\text { dense paste }\end{array}$ & $\begin{array}{l}\text { Colour: } \\
\text { white/red }\end{array}$ & Soft & $\begin{array}{l}\text { Nile valley } \\
\text { clay }\end{array}$ & $\begin{array}{l}\text { Made } \\
\text { by } \\
\text { wheel }\end{array}$ & $\begin{array}{l}\text { Painting red } \\
\text { line with } \\
\text { circle. And } \\
\text { irregularly } \\
\text { black stamp }\end{array}$ & Rim \\
\hline MER-06 & $28681^{*}$ & Royal city & $\begin{array}{l}\text { Meroitic } \\
\text { red-brown } \\
\text { utility }\end{array}$ & $\begin{array}{l}\text { Tan to } \\
\text { worm red- } \\
\text { brown }\end{array}$ & $\begin{array}{l}\text { Medium } \\
\text { fine as } \\
\text { slightly } \\
\text { porous. } \\
\text { Medium } \\
\text { hard }\end{array}$ & $\begin{array}{l}\text { Nile valley } \\
\text { clay }\end{array}$ & $\begin{array}{l}\text { Made } \\
\text { by } \\
\text { wheel }\end{array}$ & $\begin{array}{l}\text { Decorate by } \\
\text { dotted parallel } \\
\text { lines }\end{array}$ & Rim \\
\hline
\end{tabular}

*ID assort archaeological artefacts in National Corporation for antiquities and Museums, Sudan.

known culture creation of ancient Nubia, and it is rightly famed for the fine workmanship and unique decoration according to Adams [3]. The samples details shown in Table 1. General geological background to explanation somehow of the dissimilarity in the mineralogical composition of sites. The Nile, with its binary main branches - the White Nile and the Blue Nile - combine at Khartoum, runs over the county. The Atbara River, with its headstream in Ethiopia, arrives the main river system around 300 $\mathrm{km}$ north of Khartoum. The three branches have a different mineralogical composition, therefore donating to the variant in the mineralogical composition of the coming together area [4]. The White Nile brings rounded monocrystalline quartz with a minor quantity of feldspar, the sediments of the Blue Nile hold commonly mafic volcanic particles,
K-feldspar, and biotite, besides the Atbara River donates volcanic rock remains augite, and olivine. The Nile alluvium in the areas north of the union is labeled considered as extra homogeneous, enclosing mineral sets of quartz, feldspars, amphiboles, clinopyroxenes, mica, round fragments of primary volcanic rock, and phytoliths of plants, which are mostly formed from weathering of the basaltic Ethiopian Hilltops [5]. The archaeological locations of the Royal City and Meroe have together situated were located in lengthways the eastern cut banks of the Nile: Meroe is located $150 \mathrm{~km}$ north northern of Khartoum [6].

The studies stimation of firing temperature and the type of atmospheric firing phase are suitable to give condition are important to provide us a well understanding of the civilization that made 
the potteries methods [7]. Fourier transform infrared spectroscopy (FT-IR) is a useful technique to study the minerals and their decompositiontransformation manners of pottery $[8,9]$ estimate the firing condition [10] beside X-ray diffraction is alternative analytical instrument principally used for the mineral/phase investigation of potteries which informs us by the raw materials of the samples [11,12]. As well, XRF has experienced used too as co-dependent analysis that can be used, getting elements to range above Sodium to Uranium [13].
In the existent study, ancient potsherds were studied by many analytical approaches. XRD and FTIR were used for the mineralogical characterization, XRF, SEM-EDX for morphological, structural and chemical assessment. XRF for the determination of the elemental composition and SEM-EDX for morphological, structural and chemical assessment.

\section{Materials and Methods}

Six ancient Meroitic potsherds (Figure 1) were dated toward the $4^{\text {th }}$ century BC, the description of pottery samples listed in Table 1.

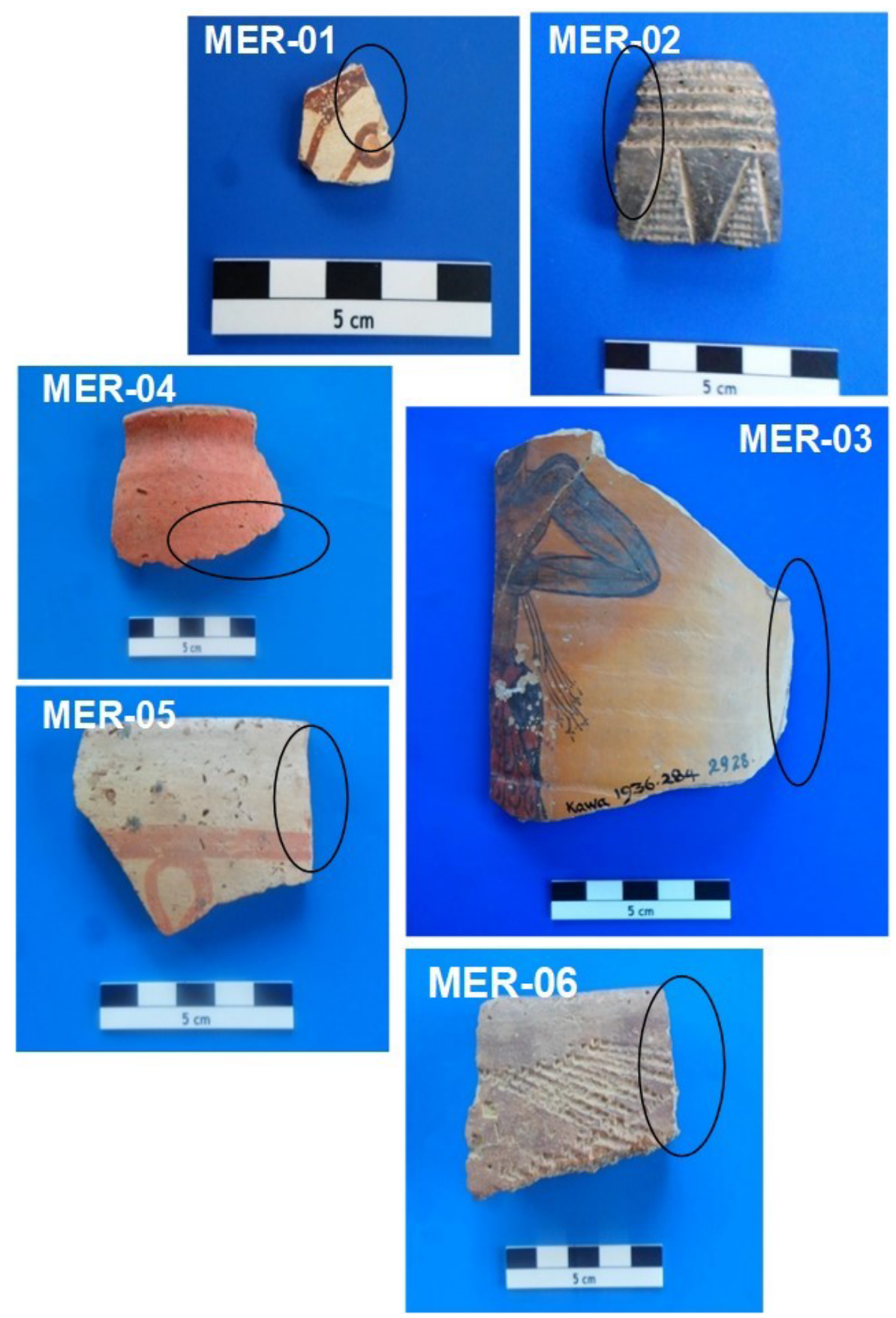

Figure 1: Photograph of Meroatic potsherds. 


\section{Fourier Transform Infrared Spectroscopy (FT-IR)}

FT-IR is obtained with FT-IR 8400 S Shimadzu (Japan) with a pyroelectric detector operating in the mid Infrared region $\left(400-4000 \mathrm{~cm}^{-1}\right)$ with a characteristic resolution of $4.0 \mathrm{~cm}^{-1}$ in transmittance mode, using $\mathrm{KBr}$ discs. The fixing of peaks and smoothing were performed by IR-solution software in the device done the working window 4000-400 $\mathrm{cm}^{-1}$.

\section{X-ray diffraction (XRD)}

X-ray diffraction (XRD) analysis was performed by EXPERT-PRO diffractometer system, the Goniometer: PW3050/60 (Theta/theta), using $\mathrm{Cu} \mathrm{K \alpha}(\lambda$ $=1.54060 \AA$ ) . The diffraction patterns were done at $2 \theta$ angle, within range $3-70^{\circ}$ with step size [ ${ }^{\circ} 2 \theta$ ] $=0.0200$ at a scan step time $0.5 \mathrm{~s}$. The measuring temperature of $25^{\circ} \mathrm{C}$, the generator sitting $40 \mathrm{~mA}$,
50 KV. The X'Pert High Score plus software was performed for diffraction data explanation.

\section{Thermogravimetric analysis (TGA)}

Thermogravimetric analysis (TGA) was carried out by PT1000 Thermogravimetric LINSEIS with thermal advantage software. The experimentation was accomplished with a heating rate $10{ }^{\circ} \mathrm{C} /$ min the samples heat up to $950{ }^{\circ} \mathrm{C}$ in high purity atmosphere.

\section{X-Ray fluorescence (XRF)}

Elemental components of the pottery were considered by X-ray fluorescence spectrometer (XRF), the samples grind down to the power by mortar and pestle, then 1 gram pressed in $2 \mathrm{~cm}^{2}$ circular disk. The X-ray isotopic source was used to measure the samples utilizing ${ }^{109} \mathrm{Cd}$ which has regular energy $22.6 \mathrm{Kev}$. Si (Li) detector, The

Table 2: FT-IR wavenumbers $\left(\mathrm{cm}^{-1}\right)$ of potsherds with corresponding vibrational assignments.

\begin{tabular}{|c|c|c|c|c|c|c|}
\hline \multicolumn{6}{|c|}{ FT-IR absorption bands in wave numbers $\left(\mathrm{cm}^{-1}\right)$ with comparative intensities } & \multirow{2}{*}{$\begin{array}{l}\text { Corresponding vibrational } \\
\text { assignments }\end{array}$} \\
\hline MER-01 & MER-02 & MER-03 & MER-04 & MER-05 & MER-06 & \\
\hline $3419 \mathrm{M}$ & $3454 \mathrm{M}$ & $3407 \mathrm{M}$ & $3438 \mathrm{M}$ & $3460 \mathrm{M}$ & $3463 \mathrm{M}$ & O-H str. Of adsorbed water \\
\hline $1622 \mathrm{M}$ & $1633 \mathrm{M}$ & $1622 \mathrm{M}$ & $1629 \mathrm{M}$ & $1623 \mathrm{~W}$ & $1639 \mathrm{M}$ & Bending of water \\
\hline $1384 \mathrm{~S}$ & $1384 \mathrm{M}$ & - & - & - & - & Calcite, carbonate stretch \\
\hline 1037 VS & $1031 \mathrm{VS}$ & 1085 VS & 1076 VS & 1081 VS & 1041 VS & Si-O Str. Of clay minerals \\
\hline 877 W & - & - & - & - & - & Out-of-plane bending $\mathrm{CO}_{3}{ }^{2-}$ \\
\hline $779 \mathrm{~W}$ & $779 \mathrm{~W}$ & $777 \mathrm{~W}$ & $781 \mathrm{~W}$ & $797 \mathrm{~W}$ & - & Si-O str. Of clay minerals \\
\hline $798 \mathrm{~W}$ & $798 \mathrm{~W}$ & 796 W & $798 \mathrm{~W}$ & $796 \mathrm{~W}$ & - & Si-O of quartz \\
\hline $694 \mathrm{~W}$ & $694 \mathrm{~W}$ & $694 \mathrm{~W}$ & $694 \mathrm{~W}$ & $692 \mathrm{~W}$ & $727 \mathrm{~W}$ & Si-O bending of quartz \\
\hline- & $638 \mathrm{VW}$ & - & - & - & $640 \mathrm{~W}$ & Al-O-Si str. Of feldspar \\
\hline $528 \mathrm{~W}$ & - & - & $532 \mathrm{VW}$ & - & - & Fe-O bend of Hematite \\
\hline $468 \mathrm{~W}$ & $466 \mathrm{VW}$ & $462 \mathrm{M}$ & $466 \mathrm{VW}$ & $462 \mathrm{VW}$ & $464 \mathrm{VW}$ & Si-O-Si bending of silicates \\
\hline $435 \mathrm{~W}$ & $433 \mathrm{VW}$ & - & $430 \mathrm{~W}$ & $439 \mathrm{VW}$ & $433 \mathrm{~W}$ & Si-O mixed vibration \\
\hline
\end{tabular}

${ }^{* *}$ S: Strong; VS: Very Strong; M: Medium; W: Weak; VW: Very Weak.

Table 3: XRD mineralogical composition of the samples.

\begin{tabular}{|l|l|l|l|l|l|}
\hline \multirow{2}{*}{ Samples code } & \multicolumn{2}{l}{ Mineral phase } & \multicolumn{2}{l|}{} \\
\cline { 2 - 4 } & Quartz & Albite & Halite & Anatase & Moganite \\
\hline MER-01 & $\neq$ & $\neq$ & $\neq$ & $\neq$ & F \\
\hline MER-02 & + & + & - & - & - \\
\hline MER-03 & + & - & + & + & - \\
\hline MER-04 & + & + & - & - & + \\
\hline MER-05 & + & - & - & - & - \\
\hline MER-06 & + & + & - & - & - \\
\hline
\end{tabular}

+ Present /-Absent / $\neq$ Not detected. 
CANBERRA amplifier model 2020 with high voltage supply $600 \mathrm{~V}$.

\section{Scanning Electron Microscope-Energy Disper- sive X-ray (SEM-EDX)}

The microphotograph analysis was performed on an EVO ${ }^{\circledR}$ LS 10 scanning electron microscope at $20 \mathrm{KV}$ an accelerating voltage and 1-3 nA a beam current. The fresh fraction of each sample coated with a thin layer of palladium/gold. The extreme magnification in the technique is 1000.0000 times. The elemental investigation was performed by using the Oxford INCA EDX energy dispersive spectrometer, for the characterization of the X-ray emitted by the sample to examine the elemental chemical composition currently identified by SEM.

\section{Results and Discussion}

\section{Mineral analysis}

The mineralogical composition of the investigated potsherds was carried out by FT- IR and XRD techniques. The FT-IR results are shown in (Figure 2 ) and listed in Table 2 within range $400-4000 \mathrm{~cm}^{-1}$. While XRD spectra are presented in (Figure $3 a$ and Figure $3 \mathrm{~b}$ ) and the crystalline minerals of XRD results listed in Table 3 . The absorption band around $1640 \mathrm{~cm}^{-1}$ is frequently assigned to $\mathrm{O}-\mathrm{H}$ bending vibration and also can arise from vibrations of the $\mathrm{SiO}_{2}$ network and is frequently hidden by water $\mathrm{O}-\mathrm{H}$ band. The absorption band around $1640 \mathrm{~cm}^{-1}$ is frequently assigned to $\mathrm{O}-\mathrm{H}$ bending vibration of water $\mathrm{O}-\mathrm{H}$ band [14]. The existence of the band around $535 \mathrm{~cm}^{-1}$ in both (MER-01, MER-04) samples, revealed that, the presence of iron oxides. Which indicated that point out these samples, they were fired in the temperature more than $750{ }^{\circ} \mathrm{C}$ in open atmosphere firing condition and it is may confirmed from the red color of the potsherds samples $[11,15]$. While sample MER-05 contains monganite which may suggest the firing temperature between $800-900{ }^{\circ} \mathrm{C}$ [16]. While MER-03 sample contains anatase, which is a common thermal stable phases impurity of both clays and sands [13]. Anatase, a $\mathrm{TiO}_{2}$ polymorph which is commonly formed over the gel or hydrothermal technique still regularly present in linkage with brookite, albite and quartz. Indeed, this phase of titanium oxide mostly transforms into rutile which is a mineral from which up to $70 \%$ of titanium oxide at about $850^{\circ} \mathrm{C}$ [17], thus, this polymorph be able to use to determine the firing temperature of ceramic [18].
Quartz basal reflection in XDR at $(4.26,2.28$, $2.24,1.85,1.54$ and $1.45 \AA$ ) while in FT-IR in the band at $694 \mathrm{~cm}^{-1}$ is linked to vibrations of Si-O bonds in mineral quartz [19], and quartz occurrence is also showed by the doublet at around 777 and 798 $\mathrm{cm}^{-1}$ [20]. Besides, the absorption bands at $475 \mathrm{~cm}^{-1}$ assigned to bending vibrations of $\mathrm{Si}-\mathrm{O}, \mathrm{Al}-\mathrm{O}$ bonds perform [21]. The bands $645 \mathrm{~cm}^{-1}$ band is due to Al-O stretching vibrations in $\mathrm{AlO}_{6}$ octahedra [22] while the band at $877 \mathrm{~cm}^{-1}$ (MER-01) attributed to the existence of calcite [12] and dehydroxylation of kaolinite minerals which is accomplished at $800{ }^{\circ} \mathrm{C}$ plus octahedral sheet structure in the clay minerals missing [23]. The existence of albite band about $435 \mathrm{~cm}^{-1}$ shows feldspar approving with XRD reflection of the Albite $(4.65,4.03,3.63,3.24,3.19$, $3.18,2.93,2.83,2.73$ and $1.97 \AA$ (in the samples (MER-02, -04, -06) $[23,24]$ shown in (Figure 3a).

The statement of the FTIR spectra pattern is in agreement with the literature, the thing makes FTIR informative is that the ability of detection of any amorphous components in the sample while XRD can analysis only crystalline phases and agreements information about the typical structure, disordered $\mathrm{SiO}_{4}$ tetrahedra in usually amorphous phases that formed through clay firing will moreover broaden this band In the firing process structural changes that happen will disturb the point of Si-O stretching and deformation bands in FTIR results [25]. The Si-O stretching bands at around $1000 \mathrm{~cm}^{-1}$ in the FTIR spectra of all pottery samples (Figure 2) shifts towards higher frequencies with increasing temperature, bands (1037, 1031 and $1041 \mathrm{~cm}^{-}$ $\left.{ }^{1}\right)$ in the samples (MER-01, MER-02 and MER-06) respectively at $700{ }^{\circ} \mathrm{C}$. While the bands $(1085,1076$ and $1081 \mathrm{~cm}^{-1}$ ) in the samples (MER-03, MER-04 and MER-05) at $900^{\circ} \mathrm{C}$. that, it is possible to estimate the firing temperature range of the samples as $700-900$ ${ }^{\circ} \mathrm{C}$, this excellent agreement with the assumption resulting from XRD and SEM-EDX [25].

\section{Thermogravimetric analysis (TGA)}

Characteristic thermal analysis curves (TGA), of the potsherds observed in heating up to $900{ }^{\circ} \mathrm{C}$ are shown in (Figure $4 \mathrm{a}$ and Figure $4 \mathrm{~b}$ ). TGA results was a complementary study to estimate the firing temperature from the specific thermal reaction in potsherds under controlled firing atmosphere combined with other spectroscopic approaches like FT-IR and XRD, for the investigation of pottery samples $[11,24]$. 

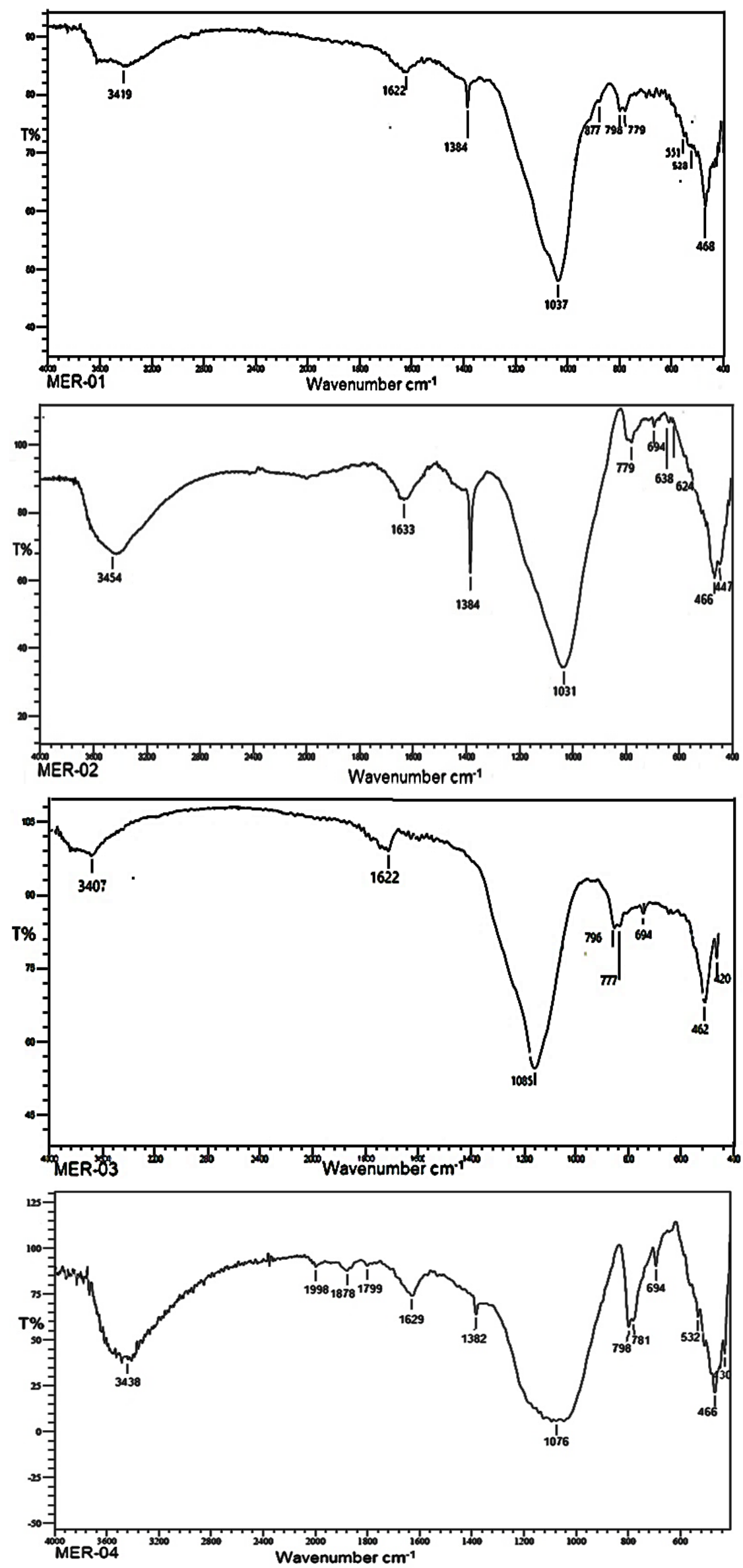

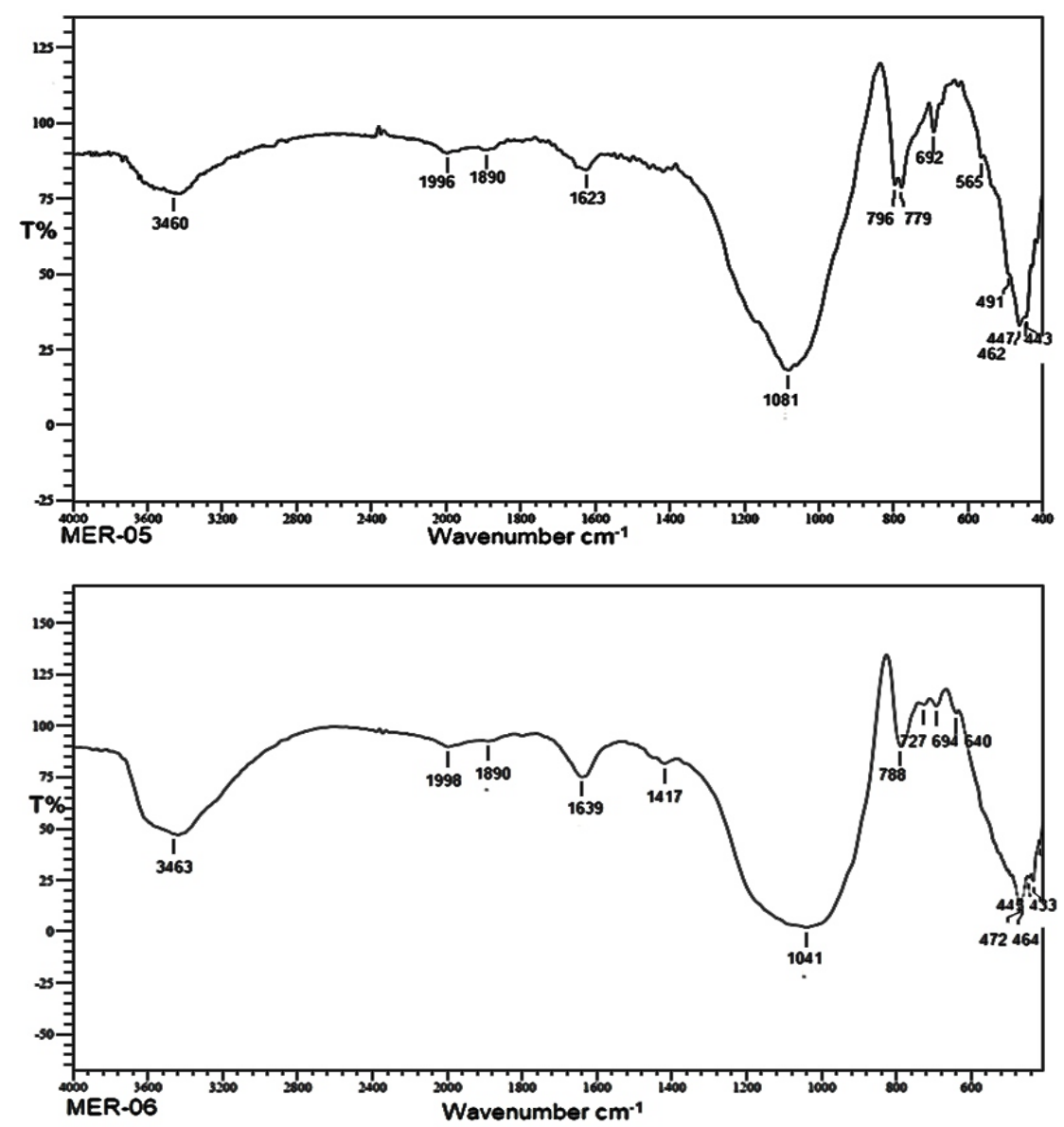

Figure 2: FT-IR spectra of the potsherds samples.

The figure characterizes the thermograms of non-calcareous (calcite-free) and calcareous (calcite-rich) potsherds. The mass-loss as a result of the thermal manner was determined by the thermogravimetric analysis (TGA). The peak pause of the dehydration and dehydroxylation were firm according to Drebushchak, et al. [26]. The peak interval of the dehydration is defined from RT (room temperature) to $350{ }^{\circ} \mathrm{C}$ and the dehydroxylation from 350 to $600{ }^{\circ} \mathrm{C}$. Even if in some potsherds dehydroxylation is not clear, the exterior of massloss in the TGA curves in the temperature interval of $350-600{ }^{\circ} \mathrm{C}$ indicates that this process takes place and can be measured. In pottery containing calcite an additional mass-loss is detected in the interval from 600 to $850{ }^{\circ} \mathrm{C}$ because of decarbonation of the calcite in the potsherds [27].

\section{X-Ray fluorescence (XRF) analysis}

The elemental analysis obtained by XRF results of the six potsherds is shown in (Figure 5 ). it is obvious that the most abundant common elements are $\mathrm{Ca}, \mathrm{Fe}$, and $\mathrm{Ti}$. The composition of $\mathrm{Fe}$ and $\mathrm{Ca}$ define the origin of the clay minerals and firing atmosphere adopted selected by the artisans. In particular, the nature of the clay whether calcareous $(\mathrm{CaO}>6 \%)$ or non-calcareous $(\mathrm{CaO}<$ $6 \%$ ) clay can be identified from the percentage of Calcium Oxides ( $\mathrm{CaO}$ ) from the XRF data, it should be noted that all the samples were non-calcareous, these suggestions show that the sources of the clay did not contain calcite $[28,29]$.

Some trace elements like $\mathrm{Mn}, \mathrm{Zr}, \mathrm{Ti}, \mathrm{Nb}$ might be used as geochemical 'fingerprints' guide, as they are related to particular petrological types [30]. The zirconium content is similarly small quantities in the samples most likely related to the igneous phases, upcoming from the granite and pegmatite regional rocks [31].

\section{SEM-EDX analysis}

The elemental concentration of the three potteries studied under SEM, beside EDX are given in (Figures 6, Figure 7 and Figure 8). The EDX indicated obviously point to low refractory clay [32] and all the three samples had relatively high iron 

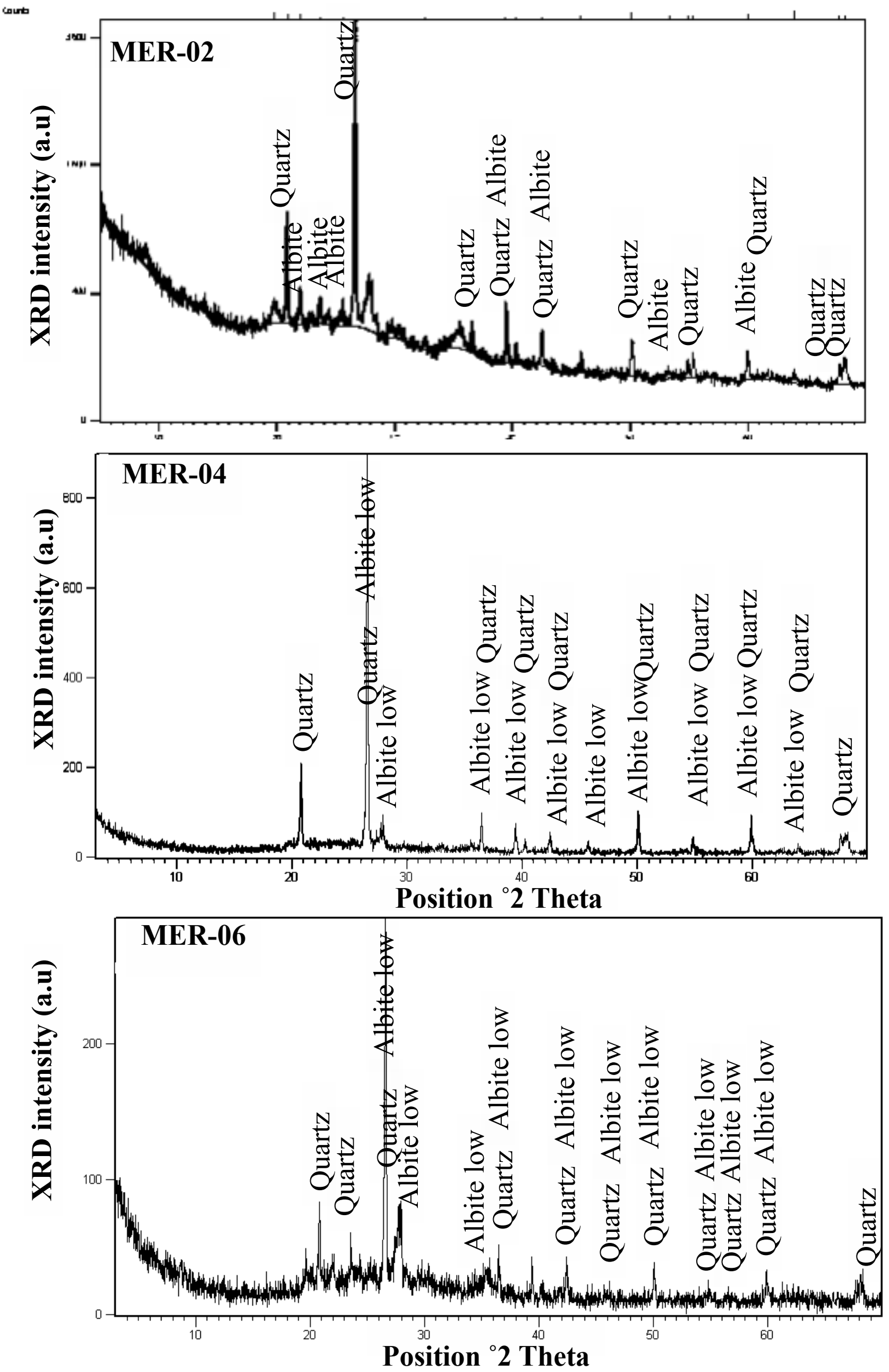

Figure 3a: XRD diffractogram of MER-02, MER-04 and MER-06. 

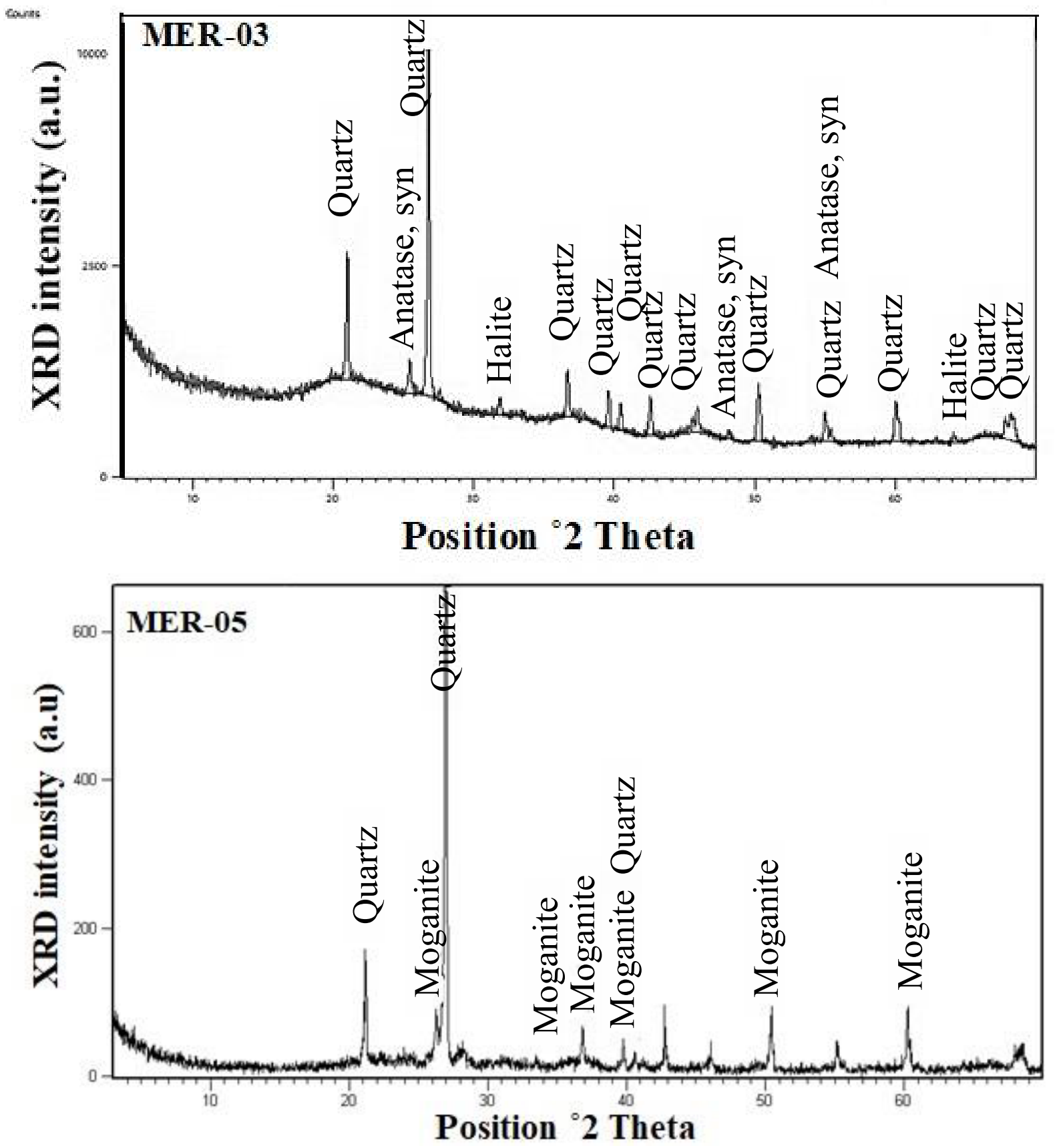

Figure 3b: XRD diffractogram of MER-03 and MER-05.

content in agreement with the chemical analysis of XRF.

The sample (MER-01) did not reveal vitrification (Figure 6) from the elemental analysis shows, it is of the non-calcareous category, according to Maniatis and Tite [33], low refractory non-calcareous clay formed in oxidizing firing condition with no vitrification stage were fired $<800^{\circ} \mathrm{C}$, The (MER-02) (Figure 7) and (MER-03) (Figure 8) samples revealed initial vitrification (IV) which supports to show the firing temperature is about $750-800{ }^{\circ} \mathrm{C}$ [33].
Furthermore, the elemental characterization by EDX spectroscopy (MER-03) (Figure 8) indication the existing of $\mathrm{O}, \mathrm{Na}, \mathrm{Mg}, \mathrm{Al}, \mathrm{Si}, \mathrm{K}, \mathrm{Ca}, \mathrm{Ti}, \mathrm{Fe}, \mathrm{Pd}$, and $\mathrm{Au}$. The elemental concentration of these elements is summarized in beside table. In the spectrum 1 area (MER-03) the elemental composition only $\mathrm{O}, \mathrm{Al}$, Si were recognized in addition very small quantities of $\mathrm{Ti}, \mathrm{Fe}, \mathrm{Au}$ may this could be planted fiber, which could have arisen naturally in the Nile clay, it is as well probably that plant ingredients might be combined to the clay as temper [6]. The composition in the another grain spectrum 2,3 areas 

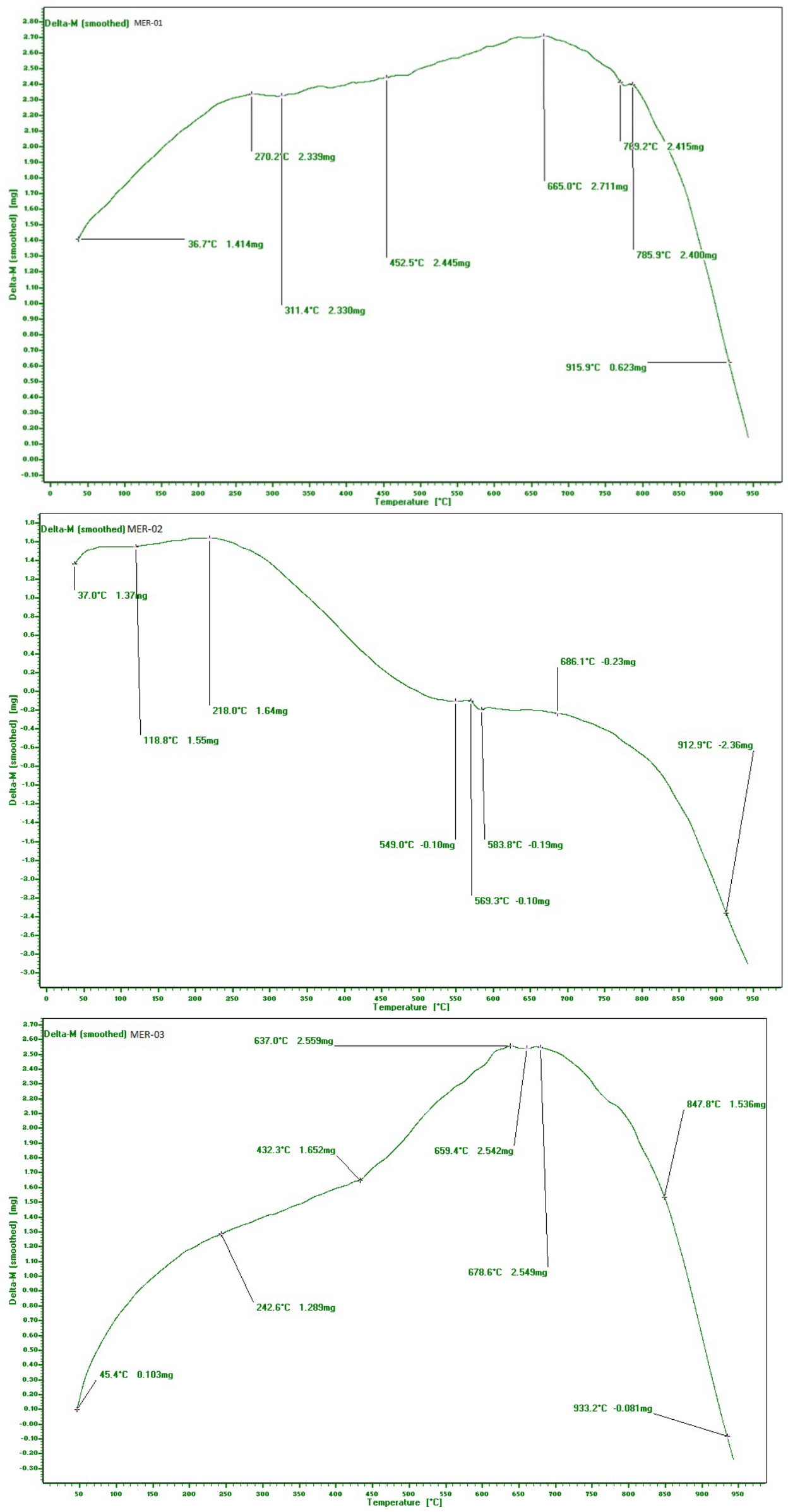

Figure 4a: Thermogravimetric curves of samples. 

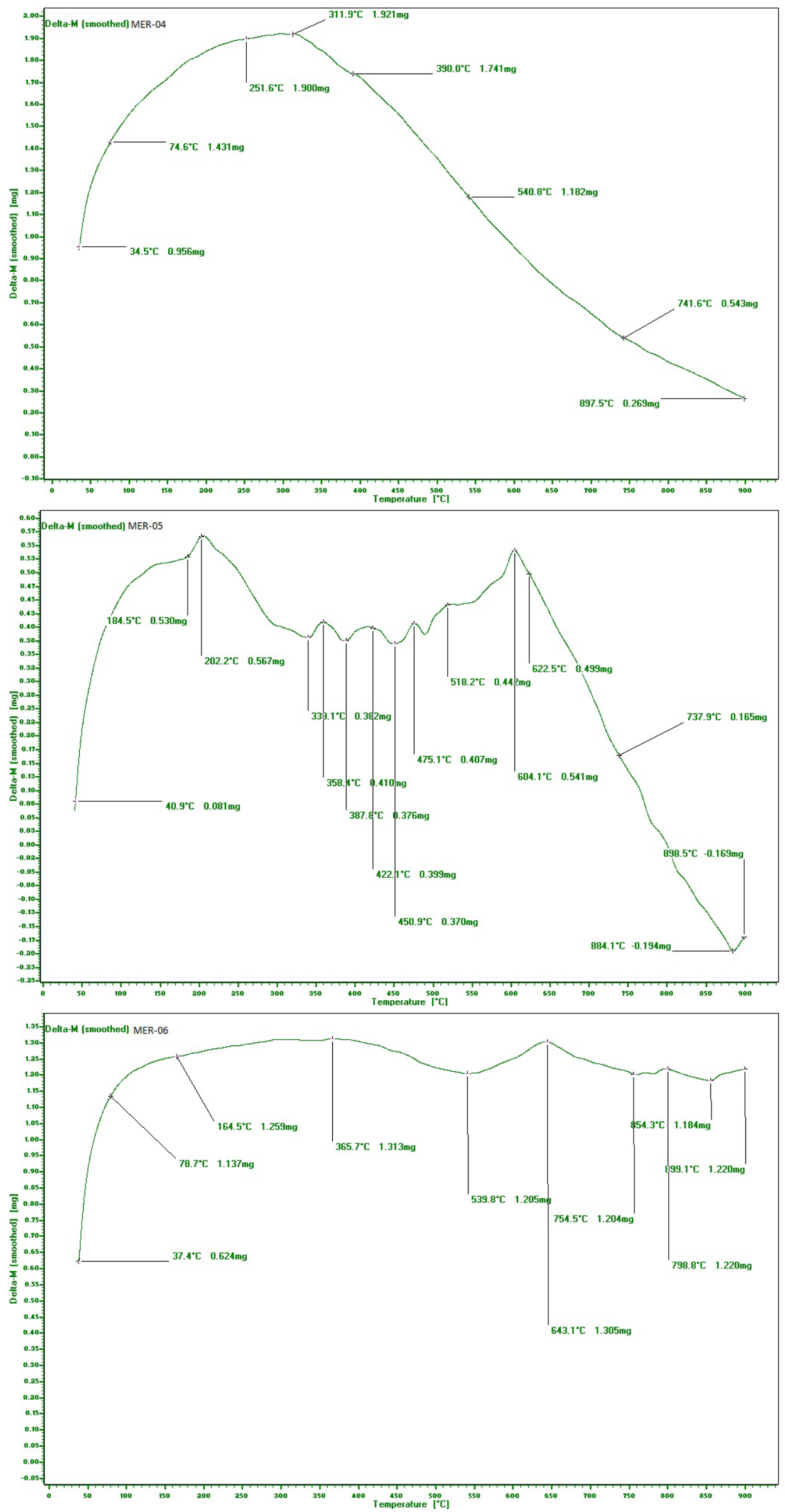

Figure $4 \mathbf{b}$ : Thermogravimetric curves of samples. 


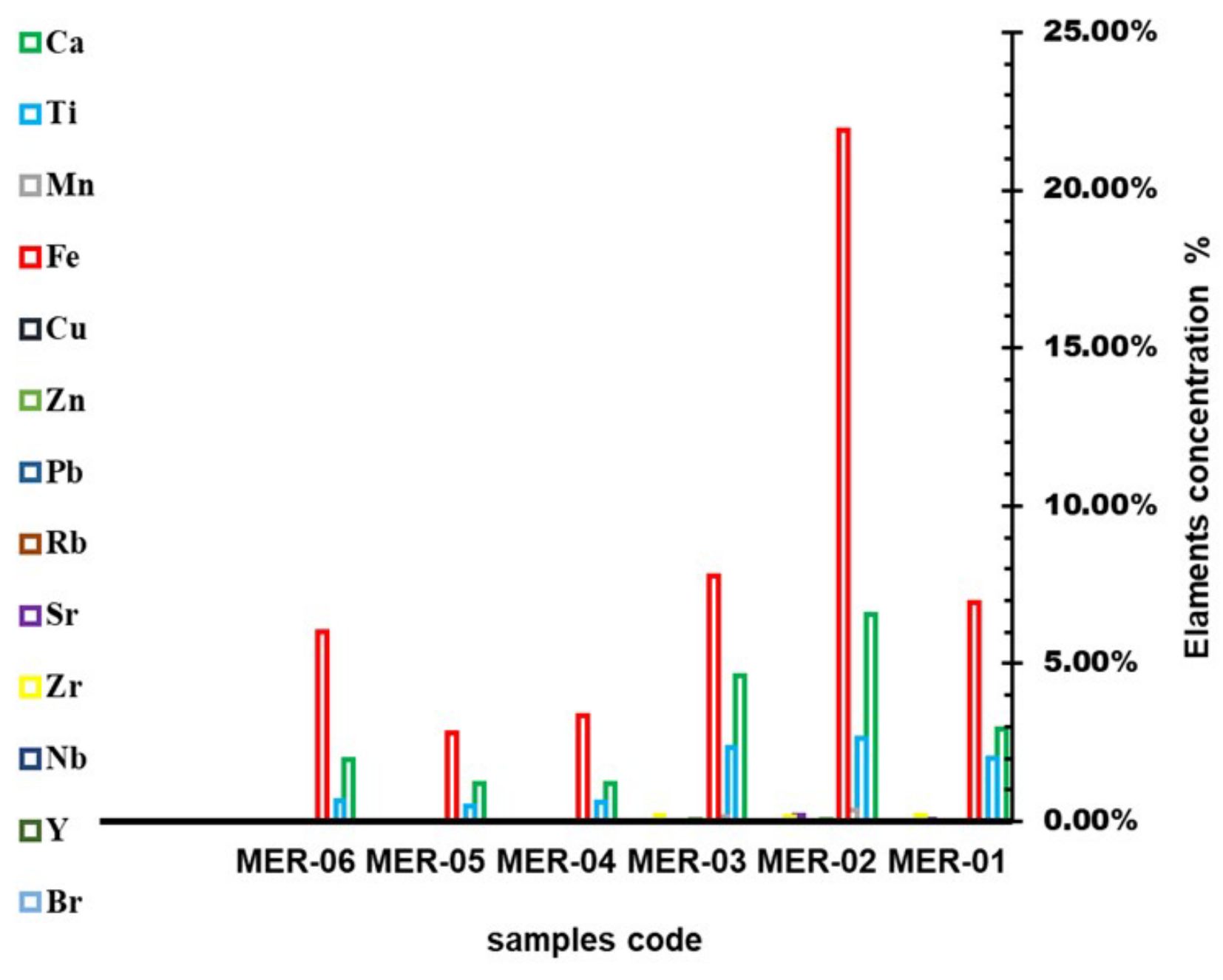

Figure 5: Elemental composition of potsherds using XRF.

are approximately different (MER-03) respectively, contain $\mathrm{Si}, \mathrm{Al}, \mathrm{O}, \mathrm{Mg}, \mathrm{Ca}$ and Fe. Furthermore, the spectrum 4 area is containing also $\mathrm{Al}, \mathrm{O}$, Si as major elements besides $\mathrm{Fe}, \mathrm{Ti}$ and $\mathrm{Au}$. The results show various samples composition, due to different raw materials used and manufacturing techniques applied by artisans [22].

\section{Conclusions}

In this paper the multi-analytical approach has been used to study the potsherds excavated in the Meroitic archaeological sites in Sudan. The results obtained showed that potsherds were made with quite different raw materials. Quartz and feldspars mineral (Albite), anatase and moganite in the XRD analysis It is confirmed with FT-IR, TGA and SEM results. As a result, may show firing temperature at $700-900{ }^{\circ} \mathrm{C}$ in oxidizing atmosphere condition. The procedural approach was well applied to the mineralogical, chemical and thermal characterization of the potsherds samples.

The chemical composition of the trace elements revealed high concentrations of characteristic elements like $\mathrm{Ti}, \mathrm{Zr}$ and $\mathrm{Nb}$. A preliminary statement that the (MER-03) was prepared at a different workshop using different clay-beds could be drawn. The primary results of this study do not necessarily imply that all the pottery of those regions are appropriate to the same chronological form have similar physicochemical characteristics. This current archaeometrical research of pottery is predictable to deliver useful evidence on pottery folklore, line of work and cultural altercation through time.

\section{Acknowledgments}

All the authors would like to thank the ArabGerman Young Academy of Sciences and Humanities (AGYA) for research funding. 

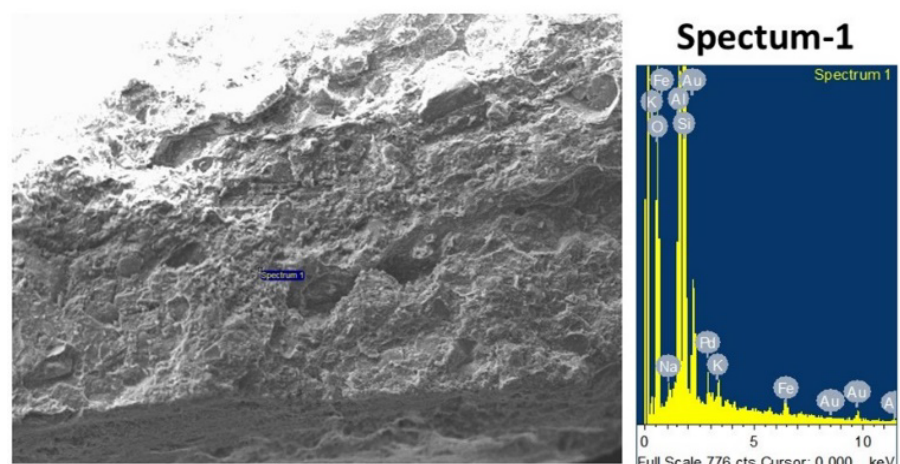

\section{MER-01}
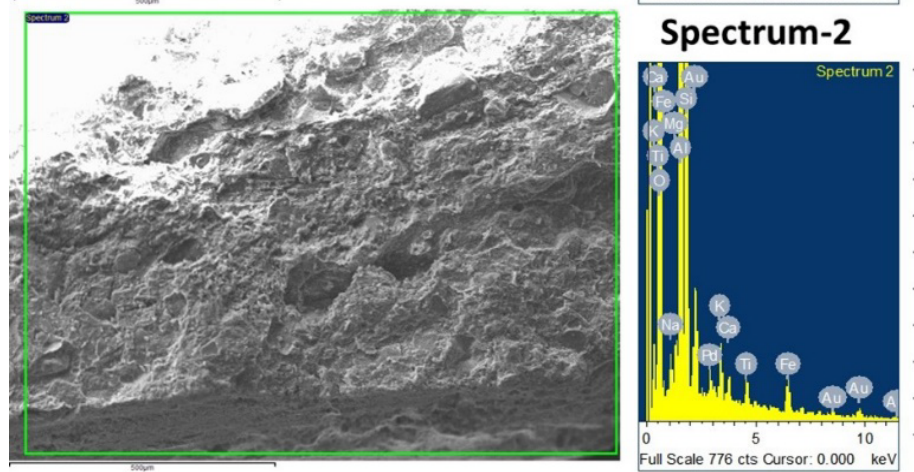

\begin{tabular}{c|c} 
Elements & At \% \\
\hline $\mathrm{O}$ & 47.42 \\
\hline $\mathrm{Na}$ & 0.49 \\
\hline $\mathrm{Al}$ & 7.23 \\
\hline $\mathrm{Si}$ & 31.03 \\
\hline $\mathrm{K}$ & 0.84 \\
\hline $\mathrm{Fe}$ & 1.12 \\
\hline $\mathrm{Pd}$ & 1.98 \\
\hline $\mathrm{Au}$ & 9.9
\end{tabular}
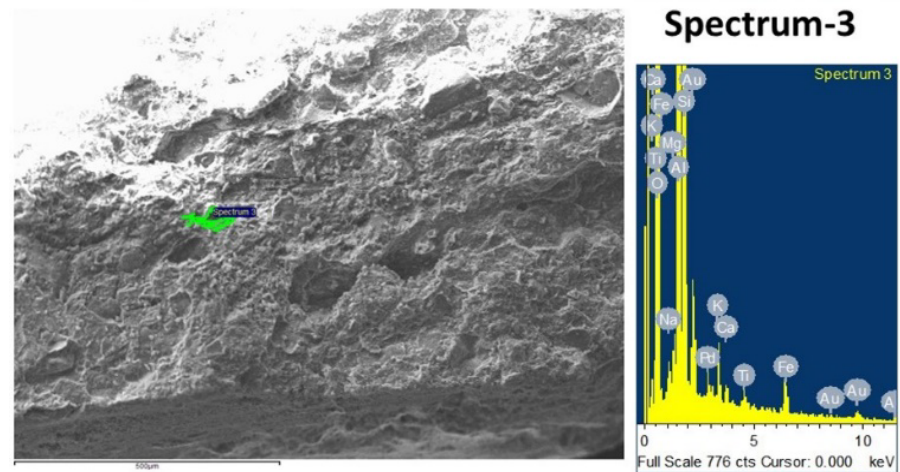

\begin{tabular}{c|c} 
Elements & At \% \\
\hline $\mathrm{O}$ & 58.54 \\
\hline $\mathrm{Na}$ & 0.41 \\
\hline $\mathrm{Mg}$ & 0.44 \\
\hline $\mathrm{Al}$ & 10.64 \\
\hline $\mathrm{Si}$ & 19.77 \\
\hline $\mathrm{K}$ & 1.15 \\
\hline $\mathrm{Ca}$ & 0.54 \\
\hline $\mathrm{Ti}$ & 0.67 \\
\hline $\mathrm{Fe}$ & 1.81 \\
\hline $\mathrm{Pd}$ & 1.22 \\
\hline $\mathrm{Au}$ & 4.81
\end{tabular}

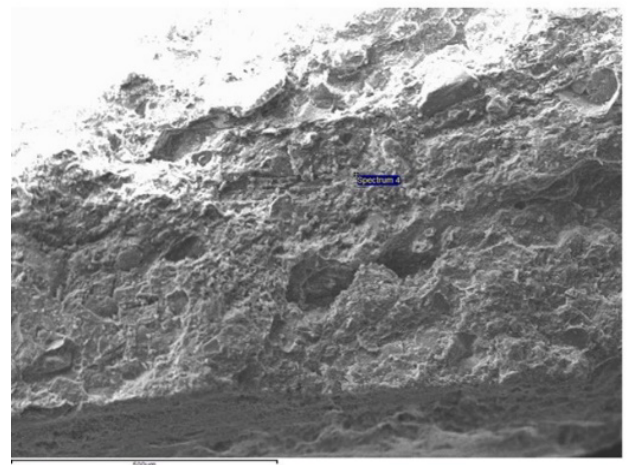

Spectrum-4
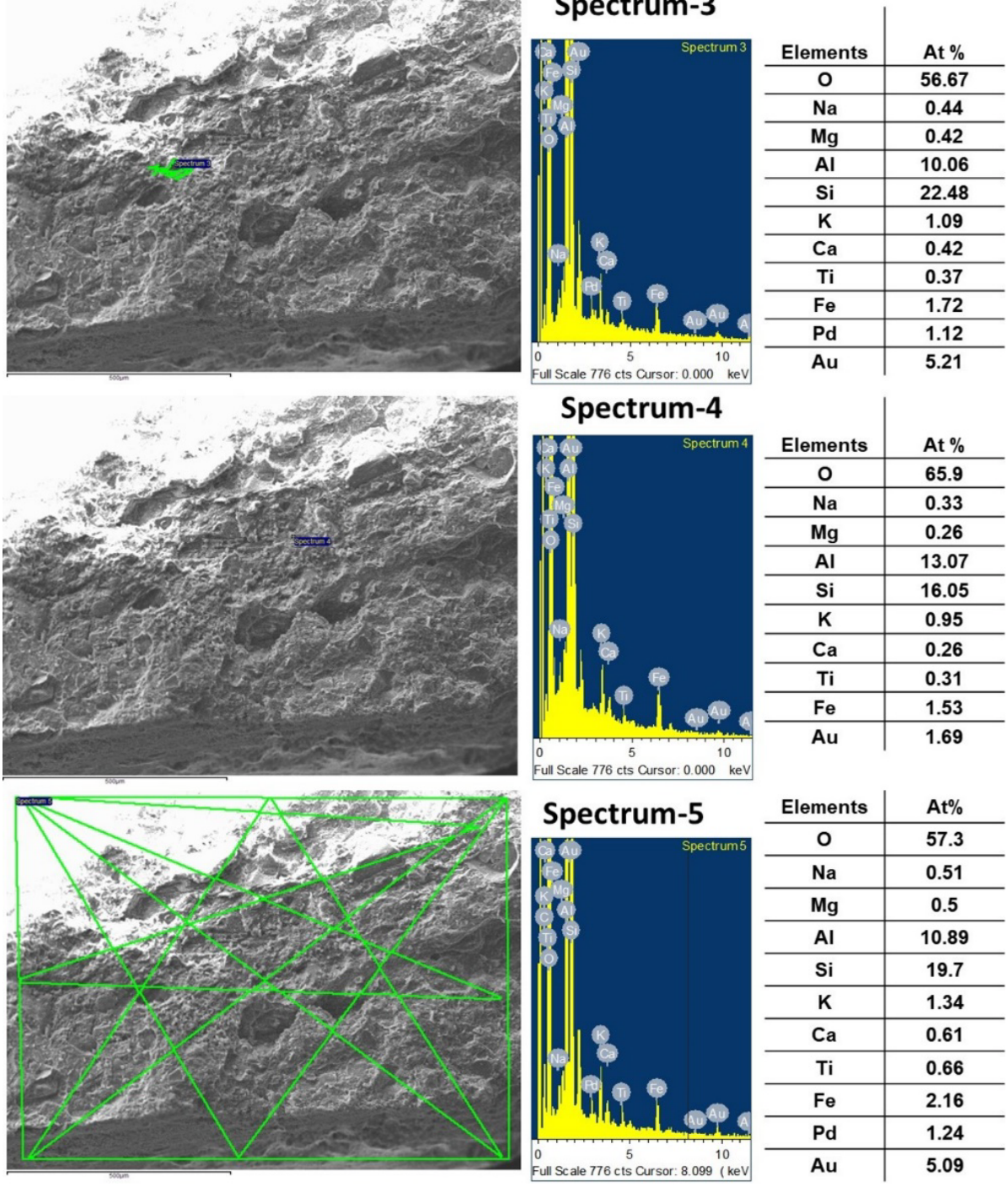

\begin{tabular}{c|c} 
Elements & At\% \\
\hline $\mathrm{O}$ & 57.3 \\
\hline $\mathrm{Na}$ & 0.51 \\
\hline $\mathrm{Mg}$ & 0.5 \\
\hline $\mathrm{Al}$ & 10.89 \\
\hline $\mathrm{Si}$ & 19.7 \\
\hline $\mathrm{K}$ & 1.34 \\
\hline $\mathrm{Ca}$ & 0.61 \\
\hline $\mathrm{Ti}$ & 0.66 \\
\hline $\mathrm{Fe}$ & 2.16 \\
\hline $\mathrm{Pd}$ & 1.24 \\
\hline $\mathrm{Au}$ & 5.09
\end{tabular}

Figure 6: SEM micrographs and EDX spectra of MER-01 potsherd. 

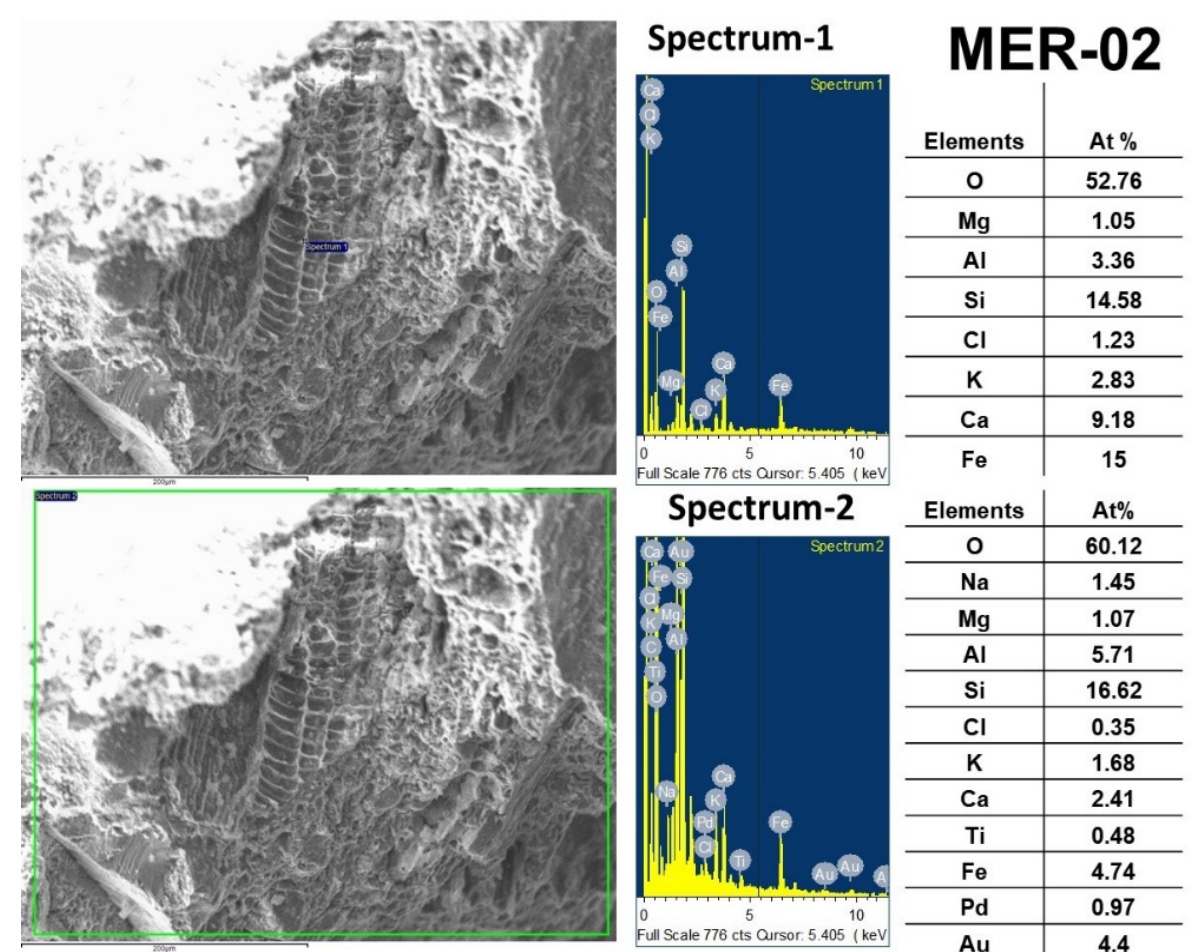

\begin{tabular}{c|c} 
Elements & At\% \\
\hline $\mathrm{O}$ & 60.12 \\
\hline $\mathrm{Na}$ & 1.45 \\
\hline $\mathrm{Mg}$ & 1.07 \\
\hline $\mathrm{Al}$ & 5.71 \\
\hline $\mathrm{Si}$ & 16.62 \\
\hline $\mathrm{Cl}$ & 0.35 \\
\hline $\mathrm{K}$ & 1.68 \\
\hline $\mathrm{Ca}$ & 2.41 \\
\hline $\mathrm{Ti}$ & 0.48 \\
\hline $\mathrm{Fe}$ & 4.74 \\
\hline $\mathrm{Pd}$ & 0.97 \\
\hline $\mathrm{Au}$ & 4.4
\end{tabular}
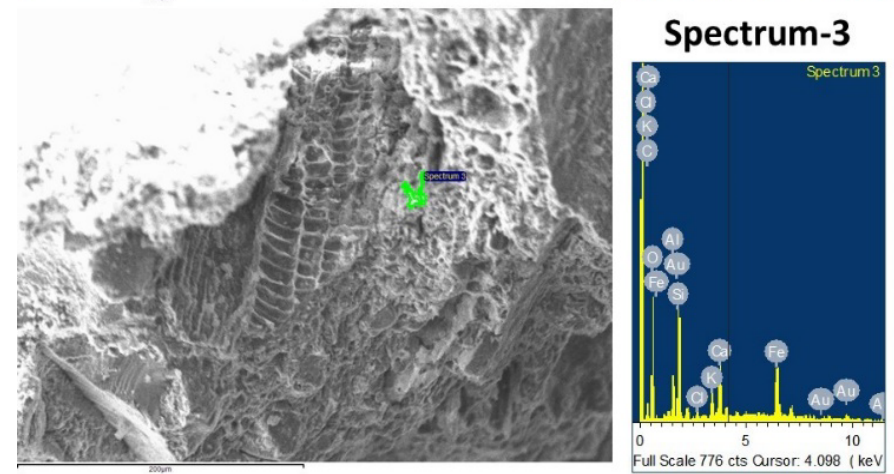

\begin{tabular}{c|c} 
Elements & At\% \\
\hline $\mathrm{O}$ & 48.33 \\
\hline $\mathrm{Al}$ & 3.68 \\
\hline $\mathrm{Si}$ & 9.68 \\
\hline $\mathrm{Cl}$ & 0.84 \\
\hline $\mathrm{K}$ & 2.89 \\
\hline $\mathrm{Ca}$ & 7.57 \\
\hline $\mathrm{Fe}$ & 23.29 \\
\hline $\mathrm{Au}$ & 3.73
\end{tabular}
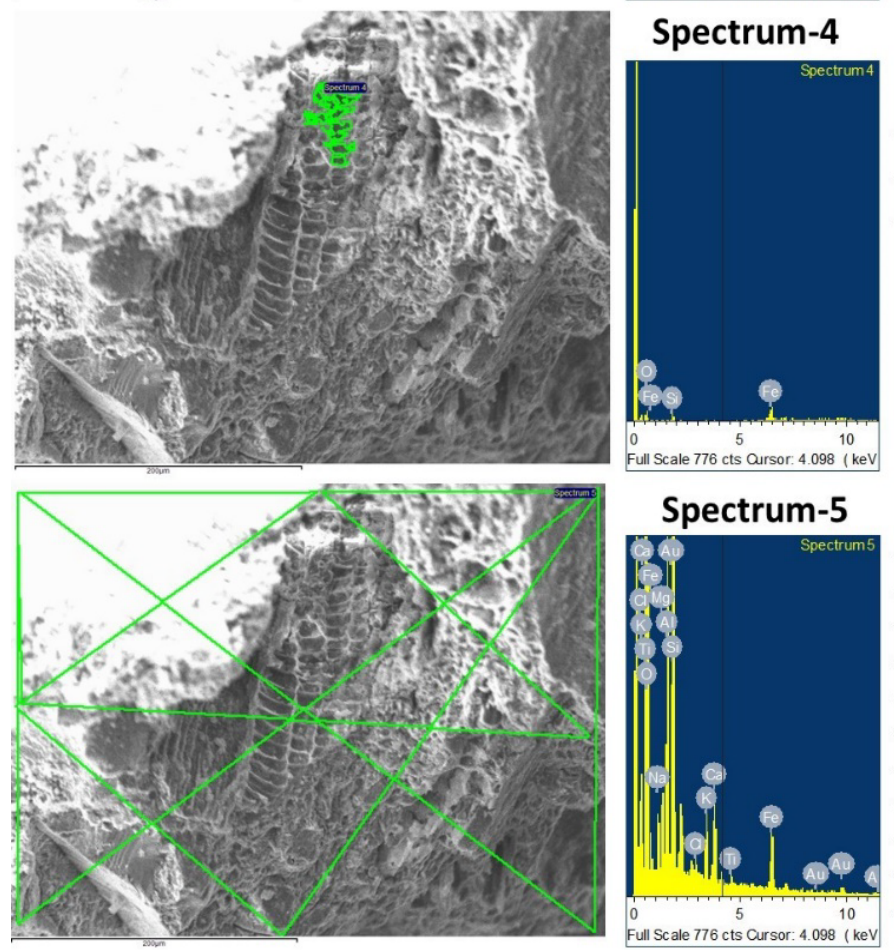

\begin{tabular}{c|c} 
Elements & At\% \\
\hline $\mathrm{O}$ & 61.28 \\
\hline $\mathrm{Na}$ & 1.38 \\
\hline $\mathrm{Mg}$ & 1.72 \\
\hline $\mathrm{Al}$ & 5.9 \\
\hline $\mathrm{Si}$ & 16.72 \\
\hline $\mathrm{Cl}$ & 0.46 \\
\hline $\mathrm{K}$ & 1.93 \\
\hline $\mathrm{Ca}$ & 2.43 \\
\hline $\mathrm{Ti}$ & 0.41 \\
\hline $\mathrm{Fe}$ & 4.62 \\
\hline $\mathrm{Au}$ & 3.62
\end{tabular}

Figure 7: SEM micrographs and EDX spectra of MER-02 potsherd. 

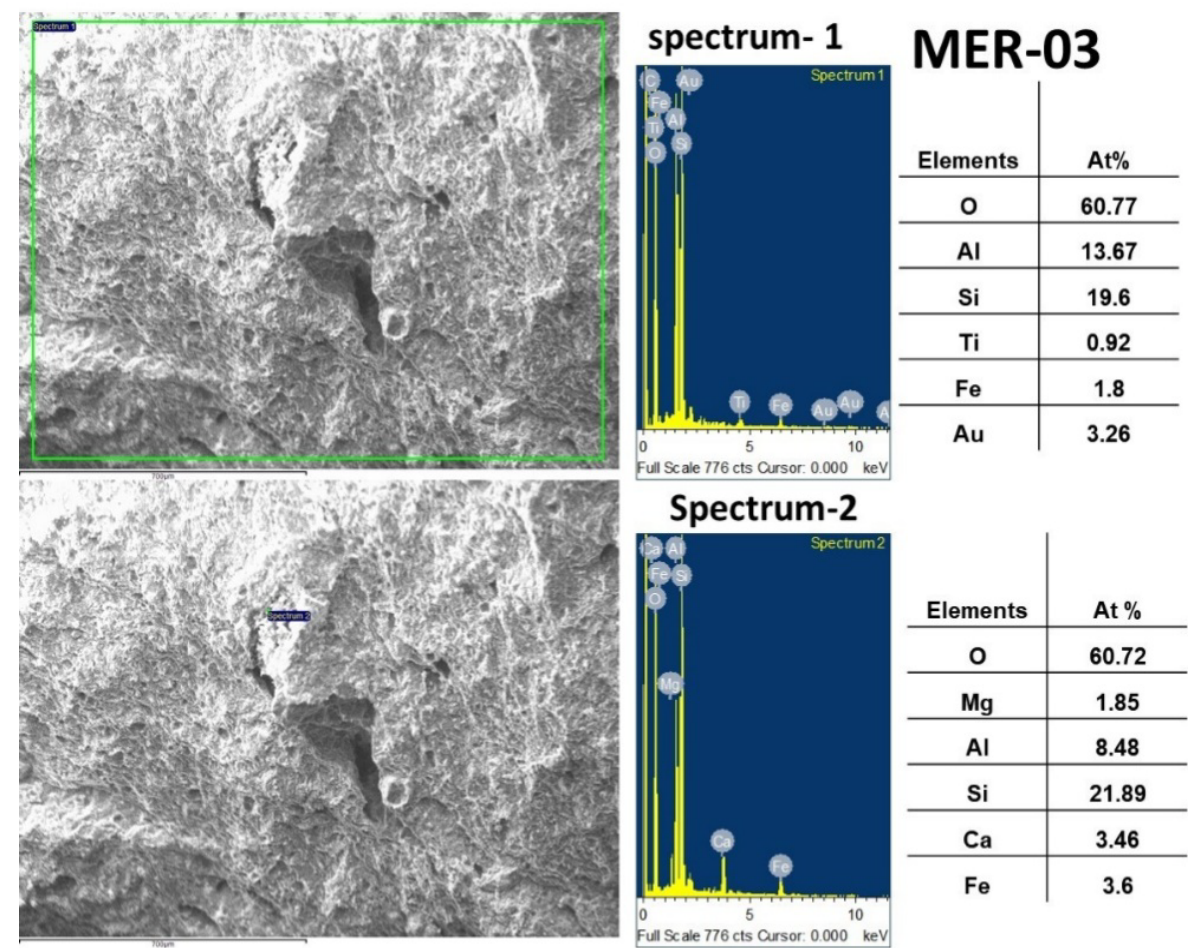

\section{Spectrum-2}

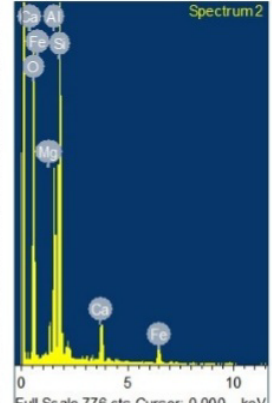

\begin{tabular}{c|c} 
& \\
Elements & At \% \\
\hline 0 & 60.72 \\
\hline $\mathrm{Mg}$ & 1.85 \\
\hline $\mathrm{Al}$ & 8.48 \\
\hline $\mathrm{Si}$ & 21.89 \\
\hline $\mathrm{Ca}$ & 3.46 \\
\hline $\mathrm{Fe}$ & 3.6
\end{tabular}

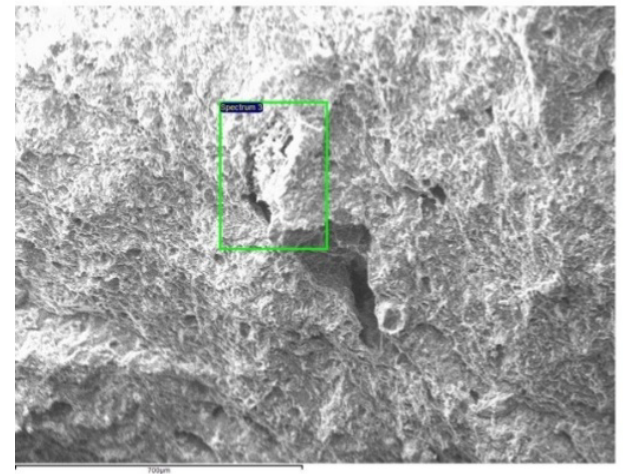

Spectrum-3
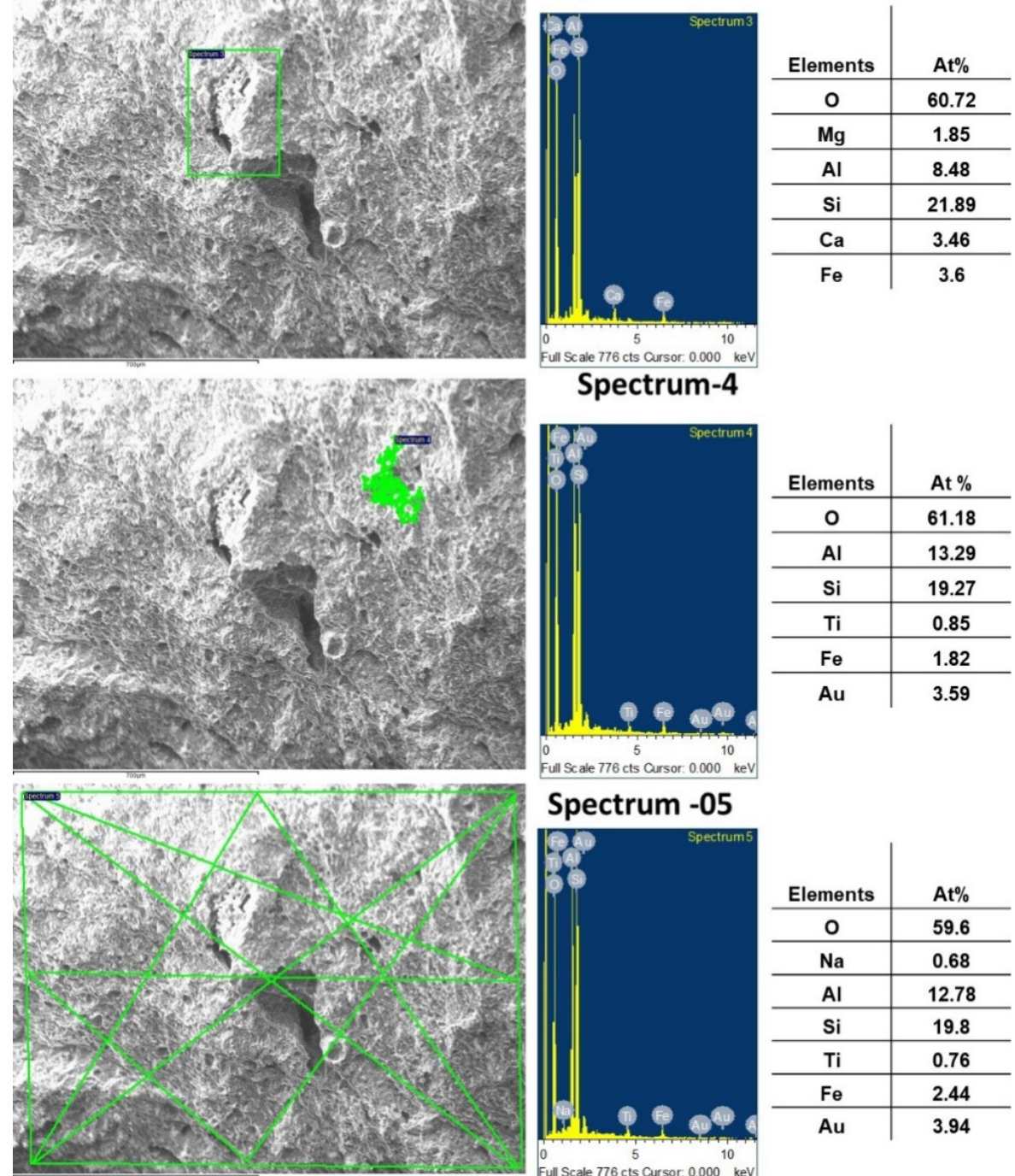

Full Scale 776 cts arsor: 0.000 keV
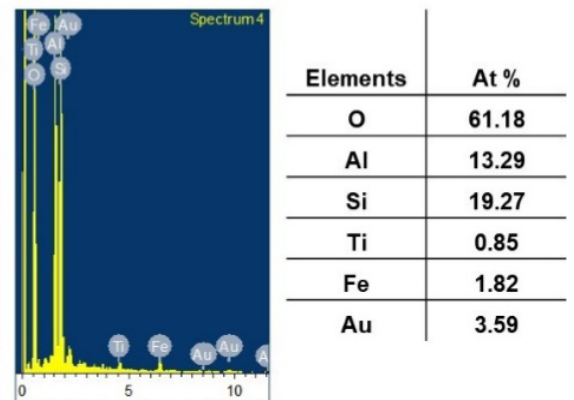

$\begin{array}{ccc}5 & 10 \\ \text { Full Scale } 776 \text { cts arsor } 0.000 \mathrm{keV}\end{array}$

Spectrum -05

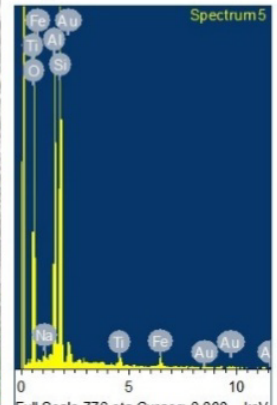

\begin{tabular}{c|c} 
& \\
Elements & At\% \\
\hline $\mathrm{O}$ & 59.6 \\
\hline $\mathrm{Na}$ & 0.68 \\
\hline $\mathrm{Al}$ & 12.78 \\
\hline $\mathrm{Si}$ & 19.8 \\
\hline $\mathrm{Ti}$ & 0.76 \\
\hline $\mathrm{Fe}$ & 2.44 \\
\hline $\mathrm{Au}$ & 3.94
\end{tabular}

Figure 8: SEM micrographs and EDX spectra of MER-03 potsherds. 


\section{References}

1. G Emberling (2004) Sudan: Ancient Treasures: An exhibition of recent discoveries from the Sudan National Museum. British Museum Publications Limited.

2. K Priese (1997) The Kingdom of Napata and Meroe, Flammarion. SAKN, Paris-New York.

3. WY Adams (1964) An introductory classification of Meroitic pottery. Kush 12: 126-173.

4. E Garzanti, S Andò, G Vezzoli, AAA Megid, A El Kammar (2006) Petrology of Nile River sands (Ethiopia and Sudan): Sediment budgets and erosion patterns. Earth Planet Sci Lett 252: 327-341.

5. RBJ Mason, K Grzymski (2009) Petrography of Pottery from Meroe, Sudan. Sudan \& Nubia, 13: 87-91.

6. C Ting, J Humphris (2017) The technology and craft organisation of Kushite technical ceramic production at Meroe and Hamadab, Sudan. J Archaeol Sci Reports 16: 34-43.

7. P Baraldi, C Baraldi, R Curina, L Tassi, P Zannini (2007) A micro-Raman archaeometric approach to Roman wall paintings. Vib Spectrosc 43: 420-426.

8. S Shoval (2003) Using FT-IR spectroscopy for study of calcareous ancient ceramics. Opt Mater 24: 117-122.

9. LM Shillito, MJ Almond, K Wicks, LJR Marshall, W Matthews (2009) The use of FT-IR as a screening technique for organic residue analysis of archaeological samples. Spectrochim Acta A Mol Biomol Spectrosc 72: 120-125.

10.R Ravisankar, S Kiruba, A Chandrasekaran, A Naseerutheen, M Seran, et al. (2010) Determination of firing temperature of some ancient potteries of Tamil Nadu, India by FT-IR spectroscopic technique. Indian J Sci Technol 3: 1016-1019.

11.R Ravisankar, G Raja Annamalai, A Naseerutheen, A Chandrasekaran, MVR Prasad, et al. (2013) Analytical characterization of recently excavated megalithic sarcophagi potsherds in Veeranam village, Tiruvannamalai dist., Tamilnadu, India. Spectrochim Acta - Part A Mol Biomol Spectrosc 115: 845-853.

12.M Bayazit, I Iskender, A Issi (2015) Investigating the firing technologies of Part-Roman potsherds excavated from Kuriki (Turkey) using thermal and vibrational spectroscopic techniques. Vib Spectrosc 78: 1-11.

13.LF Vieira Ferreira, I Ferreira Machado, AM Ferraria, TM Casimiro, P Colomban (2013) Portuguese tin-glazed earthenware from the $16^{\text {th }}$ century: A spectroscopic characterization of pigments, glazes and pastes. Appl Surf Sci 285: 144-152.

14.D Eniu, C Gruian, E Vanea, L Patcas, V Simon (2014) FTIR and EPR spectroscopic investigation of calciumsilicate glasses with iron and dysprosium. J Mol Struct 1084: 23-27.

15.P Singh, S Sharma (2016) Thermal and spectroscopic characterization of archeological pottery from Ambari, Assam. J Archaeol Sci Reports 5: 557-563.

16.JD Cashion, CA Hope, WH Jay (2015) Complementary raman and Mössbauer Archaeological studies. 39 Annu Condens MATTER Mater Meet, Australia, 3-6.

17.NQ Liem, G Sagon, VX Quang, H Van Tan, P Colomban (2000) Raman study of the microstructure, composition and processing of ancient Vietnamese (proto) porcelains and celadons (13 - 16 ${ }^{\text {th }}$ centuries). J Raman 31: 933-942.

18. HB Lucas, HJA Silva, CMS Tasayco, P Munayco, JLB Faria (2018) Archaeological pottery from Nasca culture studied by Raman and Mössbauer spectroscopy combined with X-ray diffraction. Vib Spectrosc 97: 140-145.

19.SV Sajeev, K Ramaswamy (2011) Transform infrared spectroscopy a study of firing temperature of some ancient ceramic wares using fourier transform infrared spectroscopy. AIP Conference Proceedings 137: 22-25.

20.S Shoval, P Beck (2005) Thermo-FTIR spectroscopy analysis as a method of characterizing ancient ceramic technology. J Therm Anal Calorim 82: 609616.

21.D Seetha, G Velraj (2015) Spectroscopic and statistical approach of archaeological artifacts recently excavated from Tamilnadu, South India. Spectrochim Acta - Part A Mol Biomol Spectrosc 149: 59-68.

22.O Ponta, A Vulpoi, VV Zirra, S Simon (2016) Structural and compositional investigation of ancient ceramics from a fortified settlement in south-western Romania. J Mol Struct 1122: 157-163.

23.R Ravisankar, S Kiruba, C Shamira, A Naseerutheen, PD Balaji, et al. (2011) Spectroscopic techniques applied to the characterization of recently excavated ancient potteries from Thiruverkadu Tamilnadu, India. Microchem J 99: 370-375.

24.G Raja Annamalai, R Ravisankar, A Rajalakshmi, A Chandrasekaran, K Rajan (2014) Spectroscopic characterization of recently excavated archaeological potsherds from Tamilnadu, India with multi-analytical approach. Spectrochimica Acta Part A: Molecular and Biomolecular Spectroscopy 133: 112-118. 
25.L Damjanović, I Holclajtner-Antunović, UB Mioč, V Bikić, D Milovanović, et al. (2011) Archaeometric study of medieval pottery excavated at Stari (Old) Ras, Serbia. J Archaeol Sci 38: 818-828.

26.VA Drebushchak, LN Mylnikova, TN Drebushchak (2011) The mass-loss diagram for the ancient ceramics. J Therm Anal Calorim 104: 459-466.

27.S Shoval, Y Paz (2013) A study of the mass-gain of ancient pottery in relation to archeological ages using thermal analysis. Appl Clay Sci 82: 113-120.

28.GE De Benedetto, R Laviano, L Sabbatini, PG Zambonin (2002) Infrared spectroscopy in the mineralogical characterization of ancient pottery. Journal of Cultural Heritage 3: 177-186.

29.AM Musthafa, K Janaki, G Velraj (2010) Microscopy, porosimetry and chemical analysis to estimate the fi ring temperature of some archaeological pottery shreds from India. Microchem J 95: 311-314.

30. Iordanidis, J Garcia-Guinea, G Karamitrou-Mentessidi (2009) Analytical study of ancient pottery from the archaeological site of Aiani, northern Greece. Mater Charact 60: 292-302.

31. Barış Semiza, Bahadır Duman, Mehmet Ok (2018) Analytical study of Roman red slip ware from ancient Tripolis (Denizli, Turkey). Measurement 129: 530-541.

32.Y Maniatis, MS Tite (1981) Technological examination of Neolithic-Bronze Age pottery from central and southeast Europe and from the Near East. J Archaeol Sci 8: 59-76.

33.Y Maniatis, MS Tite (1975) A Scanning electron examination of the bloating of fired clays. J Br Ceram Soc 74: 229-232. 